九州大学学術情報リポジトリ

Kyushu University Institutional Repository

\title{
First Occurrence of Cobweb Disease on Hypsizigus marmoreus Caused by Cladobotryum varium in Korea
}

Back, Chang-Gi

School of Applied Biosciences, College of Agriculture and Life Sciences, Kyungpook National University

Lee, Chang-Yun

Greenpeace Mushroom Co.

Seo, Geon-Sik

Department of Industrial Crops \& Mushrooms, Korea National College of Agriculture and Fisheries

Jung, Hee-Young

School of Applied Biosciences, College of Agriculture and Life Sciences, Kyungpook National University

他

https://doi.org/10.5109/25193

出版情報：九州大学大学院農学研究院紀要. 57 (2)，pp.373-377，2012-09-20. Faculty of Agriculture, Kyushu University

バージョン：

権利関係 : 


\title{
First Occurrence of Cobweb Disease on Hypsizigus marmoreus Caused by Cladobotryum varium in Korea
}

\author{
Chang-Gi BACK ${ }^{1}$, Chang-Yun LEE ${ }^{2}$, Geon-Sik SEO ${ }^{3}$, \\ Hee-Young JUNG ${ }^{1 *}$ and Shoji OHGA* \\ Laboratory of Forest Resources Management, Division of Agro-environmental Sciences, \\ Department of Forest Environmental Sciences, Faculty of Agriculture, \\ Kyushu University, Sasaguri, Fukuoka 811-2415, Japan \\ (Received April 4, 2012 and accepted May 10, 2012)
}

\begin{abstract}
Cobweb disease symptoms had been found on Hypsizigus marmoreus (Beech mushroom) in Cheongdo-gun, Gyeongbuk province, Korea. The symptoms were white mycelium covered fruit bodies of the mushroom and later, rotten the mushrooms. The fungus isolated from the diseased mushroom caps was identified as Cladobotryum varium based on the mycological and molecular characteristics. This is the first occurrence of cobweb disease on H. marmoreus caused by C. varium in Korea.
\end{abstract}

Keywords: Cladobotryum varium, cobweb disease, Hypsizigus marmoreus, mushroom

\section{INTRODUCTION}

Hypsizigus marmoreus (Beech mushroom) is a basidiomycete fungus which is a delicious and nutritious food and used for medicinal utilities (Lam and $\mathrm{Ng}, 2001$ ). It is popular edible mushrooms in Japan and Korea, and successfully cultivated in Korea and Taiwan (Lee et al., 2007). The natural compound of H. marmoreus has strong medical activities such as antitumour (Ikekawa et al., 1992; Ikekawa, 1995; Tsuchida et al., 1995), antifungal and antiproliferative activities (Lam and Ng, 2001). Because of these interesting functions, the production of $H$. marmoreus is being increasing worldwide. On mushrooms, the fungus; Cladobotryum species caused serious disease in all mushroom-growing countries worldwide (McKay et al., 1998). Several mushroom species had been attacked by Cladobotryum spp. such as C. dendroides, C. mycophilum, C. varium, C. multiseptatum and C. verticillatum (Mckay et al., 1999; Adie et al., 2006). Generally, chemical fungicides such as benzimidazole, were used to suppress these fungi in mushroom farms. However, C. mycophilum and C. dendroides became resistant to benzimidazole fungicides in United Kingdom. As a result of this, Cladobotryum species were difficult to manage with these fungicides (Grogan, 2006). Generally, Cladobotryum which is causal fungal of cobweb disease produce masses of conidia and they cause brown spotting symptoms on mushroom caps. In 2010 , the cobweb-like disease symptoms were observed on $H$. marmoreus in commercial mushroom farms of Cheongdo-gun of Gyeongbuk Province, Korea. The

${ }^{1}$ School of Applied Biosciences, College of Agriculture and Life Sciences, Kyungpook National University, Daegu 702-701 Korea

${ }^{2}$ Greenpeace Mushroom Co., 715 Haksan-ri, Iseo-myeon, Cheongdo-gun, Gyoengbuk, 714-853 Korea

${ }^{3}$ Department of Industrial Crops \& Mushrooms, Korea National College of Agriculture and Fisheries, Gyeonggi, 445-760 Korea

* Corresponding authors (E-mail: ohga@forest.kyushu-u.ac.jp, heeyoung@knu.ac.kr) symptoms found on $H$. marmoreus were white-mycelium covered fruit bodies of mushrooms, and massive spores were found on the fruit bodies. These spores were spread to other spawns by airflow, and the infected fruit bodies eventually became rotten and collapsed. The same symptoms are reported on cobweb disease of Flammulina velutipes caused by C. varium (Kim et al., 1999). Thus, the cobweb like disease symptoms on $H$. marmoreus was the first occurrence and any diseases on this mushroom have not been reported before in Korea. Therefore, the purpose of this study was to isolate and identify the pathogen caused cobweb disease in $H$. marmoreus using mycological and molecular methods.

\section{MATERIALS AND METHODS}

\section{Isolation and identification of fungi}

The mycelium were isolated from diseased fruit body of $H$. marmoreus and cultured on potato dextrose agar (PDA) media at $22^{\circ} \mathrm{C}$ for 3 days. To identify mycological characters, single spore was cultured on PDA at $22^{\circ} \mathrm{C}$ in the dark for 3-4 days. The shapes and sizes, color, conidia and conidiophores of isolated fungus were observed on 100 conidia by microscope. Then, the fungus was identified following the description of Gams and Hoozemans (1970).

\section{Temperature preferences and pathogenicity test}

The mycelia plugs (5 $\mathrm{mm}$ in diameter) was punched out from actively growing area of the culture by a cork borer, and placed on the center of PDA media $(90 \mathrm{~mm}$ in diameter). Then, the plates were incubated in 9 different temperatures; 5, 10, 15, 18, 20, 22, 25, 28 and $32^{\circ} \mathrm{C}$. The growth rate of the isolates was determined by measuring the diameter of mycelial colony after 8 days of incubation.

Pathogenicity tests for verifying Koch's postulates were performed on about 15 day-old mushrooms. Inoculum was prepared from 7 to 10 day-old cultures on PDA media and adjusted to $3 \times 10^{5}$ spores $\mathrm{ml}^{-1}$. The spore 
suspension $(50 \mathrm{ml})$ was sprayed on fruit bodies of $H$. marmoreus. The inoculated mushrooms were covered with plastic bags to keep the $100 \%$ humidity for 24 hours, and then, incubated at $20^{\circ} \mathrm{C}$. The disease development was observed visually after 3 days.

\section{DNA extraction and PCR amplification}

Total genomic DNA was extracted from each fungal isolate as described by Liu (Liu et al., 2000). Using a sterile toothpick, a small lump of mycelia was scraped from a 3 day-old fungal culture and transferred to a $1.5 \mathrm{ml}$ tube containing $400 \mu \mathrm{l}$ of lysis buffer $(400 \mathrm{mM}$ Tris-HCl $[\mathrm{pH}$ 8.0], $60 \mathrm{mM}$ EDTA [pH 8.0], $150 \mathrm{mM} \mathrm{NaCl}, 1 \%$ sodium dodecyl sulfate). After disruption of mycelia by sterilized plastic pestle, the tube was left at room temperature for $10 \mathrm{~min}$. The $3 \mathrm{M}$ sodium acetate $(150 \mu \mathrm{l}), \mathrm{pH} 5.2$ was added to the tube and vortexed it briefly. After centrifugation at $10,000 \times g$ for $2 \mathrm{~min}$, the supernatant was transferred to new $1.5 \mathrm{ml}$ tube and added equal volume of isopropyl alcohol. The tube was mixed by briefly inversion and centrifuged $(10,000 \times g, 2 \mathrm{~min})$ and the supernatant was discarded. The resultant DNA pellet was washed with $300 \mu \mathrm{l}$ of $70 \%$ ethanol and centrifuged $(10,000 \times g, 3 \mathrm{~min})$. The DNA pellet was air dried and dissolved in $50 \mu \mathrm{l}$ of sterilized distilled water. The total genomic DNA was frozen at $-20^{\circ} \mathrm{C}$ and used as template DNA for PCR.

The total genomic DNA was used to amplify the internal transcribed spacer (ITS) region and partial 28S rDNA of ribosomal DNAs. The ITS region and 28S rDNA region were amplified with the primer pairs of ITS1F (5'-CTT GGT CAT TTA GAG GAA GTA A-3')/ ITS4 (5'-TCC TCC GCT TAT TGA TAT GC-3') (White et al., 1990) and NL1 (5'-GCA TAT CAA TAA GCG GAG GAA AAG-3')/ NL4 (5'-GGT CCG TGT TTC AAG ACG G-3') (O'Donnell, 1993), respectively. PCR amplification was performed in $20 \mu \mathrm{l}$ of the reaction mixture containing 20ng of fungal genomic DNA, 5 unit of Taq polymerase (Solgent, Daejeon, Korea), $2 \mu \mathrm{l} 10 \mathrm{X}$ reaction buffer (100 mM Tris$\mathrm{HCl}, 400 \mathrm{mM} \mathrm{KCl}, 15 \mathrm{mM} \mathrm{MgCl}_{2}$, pH 9.0), $10 \mathrm{mM}$ dNTPs mixture and 5 pmol of each primer using Applied Biosystems 2720 thermal cycler programmed for $94^{\circ} \mathrm{C}$ for $3 \mathrm{~min}$; 35 cycles of $94^{\circ} \mathrm{C}$ for $30 \mathrm{~s}, 52^{\circ} \mathrm{C}$ for $30 \mathrm{~s}, 72^{\circ} \mathrm{C}$ for $1 \mathrm{~min}$; and $72^{\circ} \mathrm{C}$ for $7 \mathrm{~min}$ for the final extension. Amplified DNA fragments were purified using ExoSAP-IT (GE Healthcare, Buckinghamshire, UK) and followed by directly sequencing (Solgent, Daejeon, Korea) with the same primers.

\section{Sequence determination and phylogenetic analysis}

The obtained sequences were aligned using DNASTAR computer package (DNASTAR Inc.) and phylogenetic trees were constructed using the neighbor-joining method in the CLUSTAL W (Thompson et al., 1994). The phylogenetic trees for ITS region and partial of $28 \mathrm{~S}$ rDNA were obtained from the data using the program TreeView (Win32, ver. 1.6.1). Bootstrap analysis with 100 replications was performed to determine support for various clades.

\section{RESULTS AND DISCUSSION}

A cobweb-like disease of $H$. marmoreus was observed on mushroom cultivation in Chungdo-gun of Gyeongbuk province, Korea. This disease symptom was found on beech mushrooms cultivated in a greenhouse under high humidity conditions. Early symptom was white mycelium covered on the fruit bodies of young mushroom (Fig. 1A). Late symptom progressed as the infected fruit bodies became rot and masses of dry spores covered entirely on rotten mushrooms (Fig. 1B). Then, the mycelium growth spread to the caps and other fruit bodies, and finally, the diseased fruit bodies rotted rapidly. The described symptoms similar those caused by Cladobotryum species on other mushrooms.

The fungal isolates formed white mycelium on PDA media at $22^{\circ} \mathrm{C}$, and changed the color into cream color after 10 days (Fig. 2A and 2B). The conidiophores were simple branches; conidia were 2-celled, 8.6-15.8 $\mu \mathrm{m}$ long, 6.4-8.6 $\mu \mathrm{m}$ thick, ovoid shape and with big truncate basal hilum (Fig. 2C and 2D). The shape and color of fungal colony, and the shape of conidia and conidiophores were similar to those of description of Cladobotryum varium (Gams and Hoozemans, 1970). Therefore, the isolated fungus was identified as $C$. varium by its morphological characters.

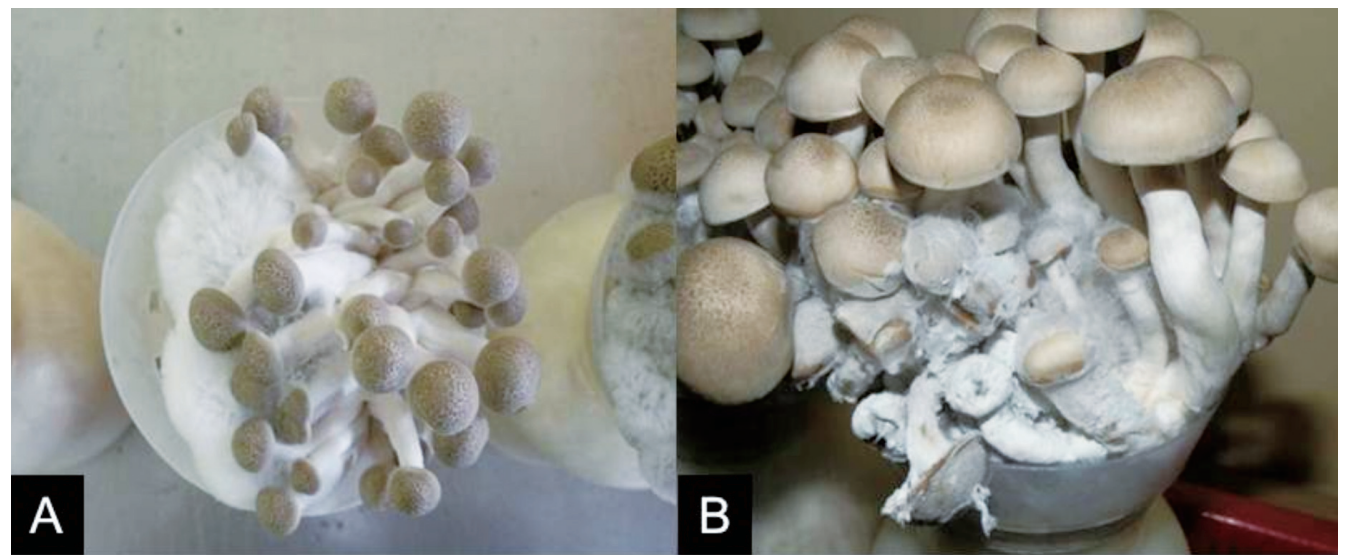

Fig. 1. Cobweb disease symptoms on H. marmoreus; Fruit bodies and caps covered with white mycelium (A); Young stage of $H$. marmoreus infected by cobweb mycelium (B). 


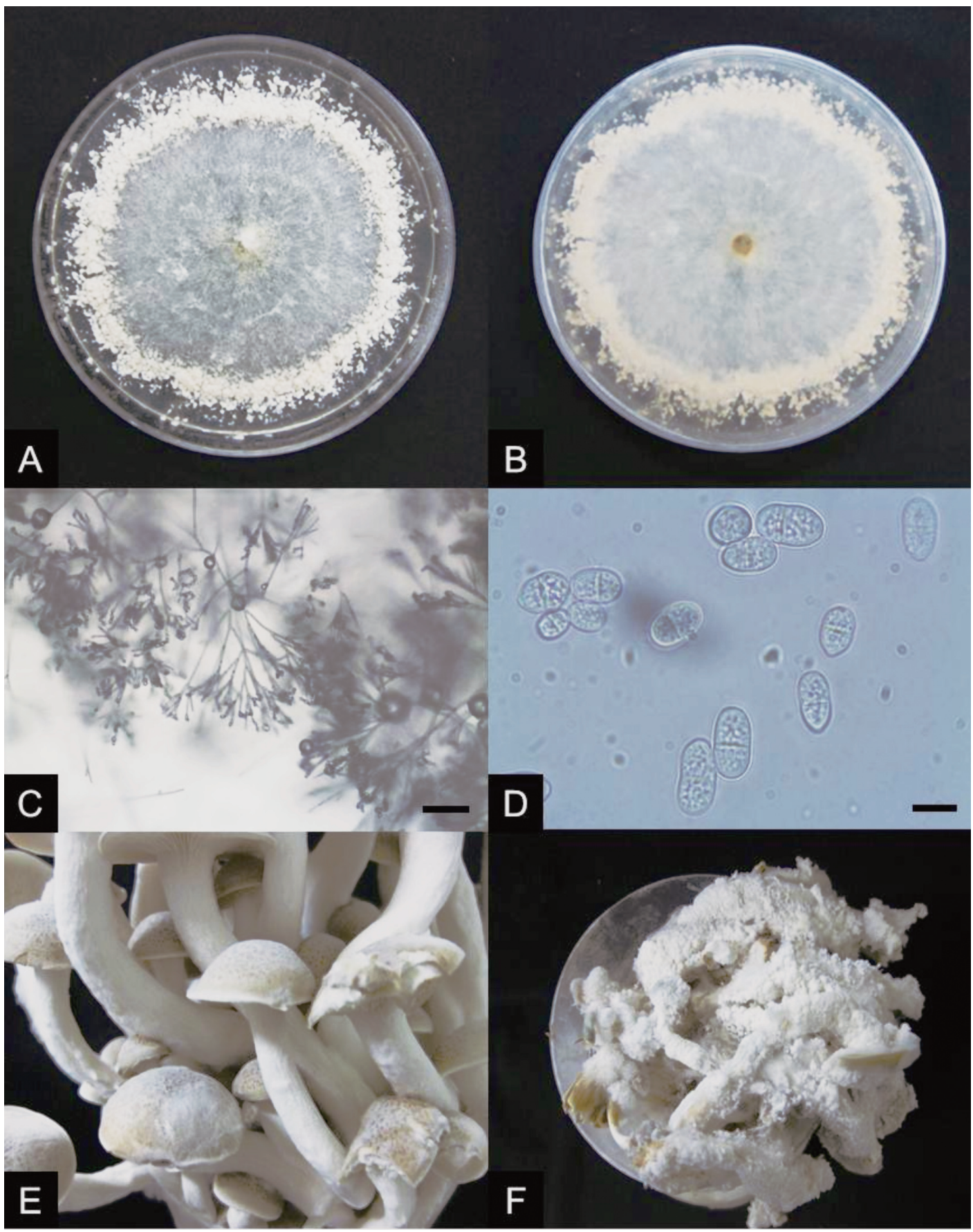

Fig. 2. Morphological characteristics of Cladobotryum varium; Front view of grey white-mycelia and dry masses of conidia in the margin of the colony (A), and back view (B) on PDA at $22^{\circ} \mathrm{C}$ for 14 days. Simple branched conidiophores (C, scale bar $=100 \mu \mathrm{m})$, and 2-celled, ovoid shaped conidia (D, scale bar $=10 \mu \mathrm{m})$ of $C$. varium. White mycelium development of $C$. varium on fruit bodies at 8 days (E) (E), and rotten fruit bodies after 19 days (F) after inoculation.

The influence of temperatures on the fungal growth was determined by colony diameter on PDA after 8 days of incubation. The rapid fungal growth was observed on $18 \sim 22^{\circ} \mathrm{C}$ with the colony diameter of $47 \sim 54 \mathrm{~mm}$ and any growth was found over $32^{\circ} \mathrm{C}$ with $0 \mathrm{~mm}$. The fungus grew slowly a range of $10 \sim 15^{\circ} \mathrm{C}$ with $14 \sim 36 \mathrm{~mm}$ (data not shown). In mushroom farms, cobweb disease outbreak was observed on temperatures ranged $15 \sim 18^{\circ} \mathrm{C}$. It can be assumed that other factors such as relative humidity in mushroom farms might favor the growth of fungus even under $18^{\circ} \mathrm{C}$.
The Koch's postulate was completed by inoculation of isolated fungi on healthy mushrooms. The same cobweb-like disease symptoms were developed on the inoculated mushroom within 8 days after inoculation (Fig. $2 \mathrm{E})$. The rotted fruit bodies and massive spores were observed within 11 days later (Fig. 2F). The disease developments on the inoculated mushrooms resembled with those on natural infection. Moreover, the symptoms were the same as reported on cobweb disease of Flammulina velutipes caused by C. varium (Kim et al., 1999). 
Molecular characterization of the isolated fungus was determined based on ITS region and partial of 28S rDNA. Direct sequencing of the PCR products amplified ITS region and partial of the $28 \mathrm{~S}$ rDNA and resulted in $642 \mathrm{bp}$ and $606 \mathrm{bp}$ respectively. All sequences of the identified isolates for each gene were 100\% identical with each other. The ITS sequence was closely related to those of Japanese isolate, $H$. aurantius (anamorph; C. varium, 99.5\%; AB298700) and the partial of the $28 \mathrm{~S}$ rDNA sequence was $100 \%$ identical with $H$. aurantius (anamorph; C. varium, AF160230). The obtained sequences of the fungus were deposited in the DDBJ/ GenBank database under the accession number of AB591044 for the ITS region and AB591045 for partial of 28S rDNA. By phylogenetic analyses of ITS region and partial of $28 \mathrm{~S}$ rDNA, the Korean isolate corresponded to Cladobotryum varium (Fig. 3A and $3 \mathrm{~B}$ ). According to results of morphological and molecular evidences, the fungal isolates from $H$. marmoreus were identified as $C$. varium.

The cobweb disease caused by $C$. varium on $H$. marmoreus had been already recorded in Japan but mor-
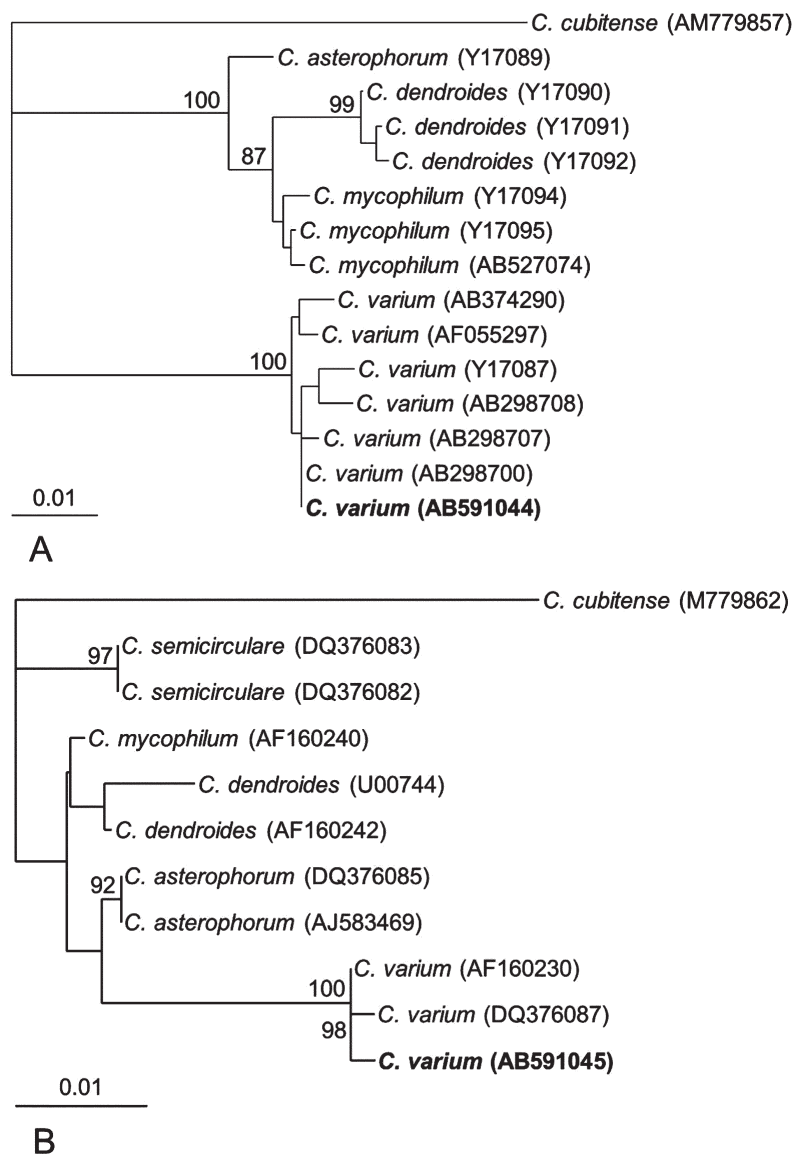

Fig. 3. Phylogenetic distance trees constructed by the neighborjoining method, comparing the ITS region (A) and partial of 28S rDNA (B) sequences of Cladobotryum varium with those of other Cladobotryum species from GenBank. Cladobotryum cubitense was used as the outgroup. Accession numbers are in parentheses. Numbers on branches are confidence values obtained for 100 replicates (only values above $80 \%$ are shown). The bar represents a phylogenetic distance of $1 \%$. phological characters of the fungus were not mentioned. In Korea, the cobweb diseases had been reported on Pleurotus eryngii and Flammulina velutipes (Kim et al., 1998; Kim et al., 1999). In cobweb disease development, temperature preference of $C$. varium growth on $P$. eryngii and $H$. marmoreus varied from $18 \sim 22^{\circ} \mathrm{C}$. In addition, conidiospore size of $C$. varium on $H$. marmoreus was smaller than those on Flammulina velutipes. In Korea, two species of $C$. varium and C. mycophilum infection had been found in mushroom farms (Kim et al., 1999; Back et al., 2010). These two species have potential to infect other mushroom species. Since the commercial impatiens are popular edible mushrooms in Japan, Korea and other Asian countries, cobweb disease has the potential to cause significant economic losses in mushroom farms, like the recent outbreaks occurred in Europe, the USA, Australia and Spain (Gaze and Fletcher, 2008; Gea et al., 2011). This agent is regarded as one of the severe pathogens in mushroom farms. To our knowledge, this is the first report of cobweb disease caused by $C$. varium on $H$. marmoreus in Korea.

\section{REFERENCES}

Adie, B., H. Grogan, S. Archer and P. Mills 2006 Temporal and spatial dispersal of Cladobotryum conidia in the controlled environment of a mushroom growing room. Appl. Environ. Microbiol., 72: 7212-7217

Back, C. G., Y-H. Kim, W-S. Jo, H. Chung and H-Y. Jung 2010 Cobweb disease on Agaricus bisporus caused by Cladobotryum mycophilum in Korea. J. Gen. Plant Pathol., 76: 232-235

Gaze, R. H. and J. T. Fletcher 2008 Mushroom pest and disease control: A color handbook. Academic Press, San Diego, CA, USA. pp. 76-79

Gea, F. J., M. J. Navarro and L. M. Suz 2011 First report of Cladobotryum mycophilum causing cobweb on cultivated king oyster mushroom in Spain. Plant Dis., 95: 1030

Grogan, H. M. 2006 Fungicide control of mushroom cobweb disease caused by Cladobotryum strains with different benzimidazole resistance profiles. Pest Manag. Sci. 62: 153-161

Ikekawa, T., H. Saitoh, W. Feng, H. Zhang, L. Li and T. Matsuzawa 1992 Antitumor activity of Hypsizigus marmoreus. I. Antitumor activity of extracts and polysaccharides. Chem. Pharm. Bull., 40: 1954-1957

Ikekawa, T. 1995 Bunashimeji, Hypsizigus marmoreus: antitumor activity of extracts and polysaccharides. Food Rev. Int., 11: 207-209

Kim, T. S., H. W. Lee, G. W. Song and W. G. Shin 1998 King oyster mushroom (Pleurotus eryngii) white mold disease caused by Cladobotryum varium. The Korean Society of Mycology, News Letter, 11: 46

Kim, H. K., S. J. Seok, G. P. Kim, B. J. Moon and T. Terashita 1999 Occurrence of disease caused by Cladobotryum varium on Flammulina velutipes in Korea. Kor. J. Mycol., 27 . 415-419

Lam, S. K. and T. B. Ng 2001 Hypsin, a novel thermostable ribosome-inactivating protein with antifungal and antiproliferative activities from fruiting bodies of the edible mushroom Hypsizigus marmoreus. Biochem. Biophys. Res. Commun., 285: 1071-1075

Lee, Y-L., M. T. Yen and J. L. Mau 2007 Antioxidant properties of various extracts from Hypsizigus marmoreus. Food Chem., 104: 1-9

Liu, D., S. Coloe, S. Baird and J. Pedersen 2000 Rapid minipreparation of fungal DNA for PCR. J. Clin. Microbiol., 38: 471 
McKay, G. J., D. Egan, E. Morris and A. E. Brown 1998 Identification of benzimidazole resistance in Cladobotryum dendroides using a PCR-based method. Mycol. Res., 102: $671-676$

McKay, G. J., D. Egan, E. Morris, C. Scott and A. E. Brown 1999 Genetic and morphological characterization of Cladobotryum species causing cobweb disease of mushrooms. Appl. Environ. Microbiol., 65: 606-610

O'Donnell, K. 1993 Fusarium and its near relatives. In: The fungal holomorph: mitotic, meiotic and pleomorphic speciation in fungal systematic, ed. By Reynolds R, Taylor JW CAB International, Wallingford, UK. pp. 225-233

Tsuchida, K., Y. Aoyagi, S. Odani, T. Mita and M. Isemura 1995
Isolation of a novel collagen-binding protein from the mushroom, Hypsizigus marmoreus, which inhibits the Lewis lung carcinoma cell adhesion to type IV collagen. J. Biol. Chem., 270: 1481-1484

Thompson, J. D., D. G. Higgins and T. J. Gibson 1994 CLUSTAL W: improving the sensitivity of progressive multiple sequence alignment through sequence weighting, position-specific gap penalties and weight matrix choice. Nucl. Acids Res. 22: $4673-4680$

White, T. J., T. Bruns, S. Lee and J. Taylor 1990 Amplification and direct sequencing of fungal ribosomal RNA genes for phylogenetics. PCR Protocols: A Guide to methods and applications, Academic Press, San Diego, CA, USA. pp. 315-322 